\title{
Penukaran tanah wakaf masjid agung Semarang dalam perspektif fikih istibdāl
}

\author{
Ahmad Furqon \\ Fakultas Ekonomi dan Bisnis Islam UIN Walisongo Semarang \\ Email:ahmadfurqonws@gmail.com \\ DOI: 10.18326/ijtibad.v17i1. 39-60
}

Substitution of waqf land is one of nażir (waqf fund manager) efforts to make waqf lands managed more productive. Semarang Mosque Welfare Council (BKM), as nažir, has made three substitutions of Semarang Grand Mosque waqf lands. Those three-time substitutions leaved problems causing to poor results of the waqf lands managed. This study is aimed at finding out the substitution process of Semarang Grand Mosque waqf lands and the pespective of Istibdäl Fiqh on substitutions of Semarang Grand Mosque waqf lands. This study is a case study. The data collection techniques are observation, interview, and documentation. The interview is conducted to parties who know the substitution case of Semarang Grand Mosque waqflands. The data collected are analyzed descriptively. The results of this study are: 1) the first substitution of Semarang Grand Mosque waqflands, made with PT Sambirejo, is not based on in-depth research especially on land replacement. The party invited to conduct the transaction, Cipto Siswoyo from PT. Sambirejo, his testimony is categorized unacceptable due to fraud. 2) The second substitution of Semarang Grand Mosque waqflands, which is in the form of money to establish $M a^{\prime} h a d A l y$, is less rocommended by fiqh scholars since the money value tends to decline, and is prone to corrupt and abuse. Moreover, Ma'had Aly has not established yet during the substitution process happened in 2008 to 2016. 3) The third substitution of Semarang Grand Mosque waqf lands employs substitute money used to purchase substitute lands. This is considered appropriate and the price of the substitute lands refers to the market price.

Penukaran tanah wakaf merupakan salah satu upaya nazhir dalam memproduktifkan tanah wakaf yang dikelola. Badan Kesejahteraan Masjid (BKM) Kota Semarang selaku nazhir telah melakukan 3 (tiga) kali penukaran Tanah wakaf Masjid Agung Semarang. Tiga kali penukaran tanah wakaf Masjid Agung Kota Semarang yang dilakukan oleh BKM Kota Semarang menyisakan permasalahan-permasalahan yang mendatangkan hasil yang kurang baik bagi tanah wakaf yang dikelola. Rumusan masalah dalam penelitian pertama, bagaimana proses penukaran Tanah wakaf Masjid Agung Semarang? Bagaimana penukaran tanah wakaf Masjid Agung Semarang dalam perspektif fikih Istibdal?. Penelitian ini studi kasus dengan teknik pengumpulan data yang dilakukan melalui observasi, wawancara, dan dokumentasi. Wawancara 
ljthad, Jurnal Wacana Hukum Islam dan Kemanusiaan, Volume 17, No. 1, Juni 2017: 39-60

dilakukan kepada pihak-pihak yang mengetahui kasus penukaran tanah wakaf Masjid Agung Semarang. Data telah terkumpul kemudian dianalisis secara deskriptif. Hasil penelitian mengungkap 1). Penukaran tanah wakaf Masjid Agung Semarang yang pertama dengan PT Sambirejo tidak dilakukan penelitian secara mendalam terhadap tanah pengganti. Orang yang diajak melakukan transaksi dalam hal ini Cipto Siswoyo, dari PT. Sambirejo, masuk kategori yang tidak bisa diterima kesaksiannya, karena melakukan penipuan; 2). Penukaran tanah wakaf Masjid Agung Semarang yang kedua, berupa uang untuk pembangunan Ma'had Aly, kurang dianjurkan oleh para ulama Fikih, karena nilai uang yang cenderung turun, dan rentan untuk dikorupsi dan disalahgunakan. Apalagi peristiwa penukaran terjadi tahun 2008, dan sampai tahun 2016, Ma'had Aly tersebut belum berdiri; 3). Penukaran tanah wakaf Masjid Agung Semarang yang ketiga adalah juga dengan uang pengganti yang kemudian dibelikan tanah pengganti. Hal tersebut sudah tepat dan harga tanah pengganti masuk dalam harga pasar.

Keywords: Substitution; Semarang Grand Mosque; waqf lands; Istibdal Fiqh

\section{Pendahuluan}

Penukaran tanah wakaf merupakan salah satu upaya nazhir dalam memproduktifkan tanah wakaf yang dikelola. Dengan penukaran tanah wakaf diharapkan tanah penukar dapat lebih produktif, hingga memberikan hasil yang dapat dirasakan manfaatnya oleh penerima wakaf atau masyarakat. Untuk melakukan penukaran, nazhir perlu melakukan kehati-hatian, agar keputusan penukaran yang diambilnya tidak mengakibatkan kerugian atau hilangnya tanah wakaf tersebut.

Bondo Masjid Agung Semarang, adalah sebutan bagi tanah wakaf milik Masjid Agung Semarang. Bondo Masjid Agung Semarang berasal dari wakaf Ki Ageng Pandan Arang saat menjabat menjadi bupati Semarang. Berdasarkan KMA No.11 tahun 1965, luas bondo Masjid Agung Semarang adalah 125,713 ha. Adapun yang menjadi nazhir bondo Masjid Agung Semarang adalah Badan Kesejahteraan Masjid (BKM) Kota Semarang. BKM adalah organisasi semi resmi yang berada di Kementerian Agama. Penunjukkan BKM Kota Semarang sebagai nazhir adalah berdasarkan KMA No.92 Tahun 1962.

BKM Kota Semarang telah melakukan 3 (tiga) kali penukaran Tanah wakaf Masjid Agung Semarang. Penukaran pertama terjadi pada tahun 1985, yaitu penukaran Tanah wakaf Masjid Agung Semarang yang berlokasi di Kota Semarang seluas $1.191 .170 \mathrm{~m}^{2}$, dengan tanah penukar dari PT. Sambirejo yang berlokasi di Kabupaten Demak seluas 2.504.272 $\mathrm{m}^{2}$. Penukaran kedua adalah penukaran Tanah wakaf Masjid Agung Semarang dengan bangunan gedung Ma'had Aly pada tahun 2008. Sedangkan penukaran ketiga adalah 
penukaran tanah wakaf Masjid Agung Semarang yang menjadi jalan tembus Jolotundo dengan uang pengganti dari Pemerintah Kota (Pemkot) Semarang pada tahun 2015.

Tiga kali penukaran tanah wakaf bondo Masjid Agung Semarang yang dilakukan oleh BKM Kota Semarang menyisakan permasalahan-permasalahan yang mendatangkan hasil yang kurang baik bagi tanah wakaf yang dikelola. Penukaran pertama dengan PT. Sambirejo, ternyata tanah penukar dari PT. Sambirejo sebagian besar adalah tanah fiktif atau bersertifikat palsu. Dari 250 ha tanah yang dijanjikan sebagai penukar, hanya 66,2 ha yang ada tanahnya dan bersertifikat BKM, sedangkan $1.842 .176 \mathrm{~m}^{2}$ adalah fiktif (Yusuf, 2000:48-49). Penukaran kedua berupa gedung Ma'had Aly, ternyata yang diserahkan bukan berbentuk gedung akan tetapi berupa uang sejumlah Rp. 6.122.500.000,- (enam milyar seratus dua puluh dua juta lima ratus ribu rupiah) (KMA No. 114 Tahun 2008 tentang Izin Perubahan Status Tanah Wakaf terletak di Kel.Sambirejo Kec. Gayamsari Kota Semarang Provinsi Jawa Tengah menjadi Jalan Raya Tembus dari Jalan Sukarno-Hatta menuju Masjid Agung Jawa Tengah dengan Penggantian Berupa Sejumlah Uang untuk Pembangunan Gedung Ma’had Aly). Sedangkan penukaran ketiga atas tanah bondo Masjid Agung Semarang yang menjadi jalan tembus Jolotundo, sampai jalan tersebut telah resmi dipakai menjadi jalan umum, belum ada tanah pengganti atau uang pengganti yang diberikan Pemkot Kota Semarang sebagai penukar dari tanah wakaf tersebut (http://berita.suaramerdeka.com/pembebasan-jalurjolotundo-rampung, diakses tanggal 5 Mei 2016).

Ketiga kasus penukaran tanah wakaf Masjid Agung Semarang ini menarik untuk dikaji. Pertanyaan besar yang muncul adalah mengapa penukaran Tanah wakaf Masjid Agung Semarang yang direncanakan agar tanah tersebut menjadi produktif dan mendatangkan keuntungan malah mendatangkan kerugian terhadap tanah wakaf tersebut. Karena perlu dilihat bagaimana penukaran wakaf dalam perspektif fikih istibdāl wakaf. Maka rumusan masalahnya, bagaimana proses penukaran tanah wakaf Masjid Agung Semarang? Bagaimana penukaran tanah wakaf Masjid Agung Semarang dalam perspektif fikih istibdä?

Tujuan penelitian untuk mengetahui proses penukaran tanah wakaf Masjid Agung Semarang, dan untuk mengetahui bagaimana penukaran Tanah wakaf Masjid Agung Semarang tersebut dalam perspektif fikih istibdāl. Penelitian ini diharapkan dapat menjadi pedoman nazhir dalam mengelola tanah wakaf terutama dalam melakukan penukaran tanah 
ljthad, Jurnal Wacana Hukum Islam dan Kemanusiaan, Volume 17, No. 1, Juni 2017: 39-60

wakaf agar tidak mendatangkan kerugian atas tanah wakaf yang ditukar sehingga kemanfaatan dari penukaran tersebut dapat dicapai.

\section{Pengertian istibdāl wakaf}

Secara bahasa kata istibdāl adalah bentuk masdar dari kata istabdala, yang berarti tagayyara, harrafa, atau gayyarabu bi gairih, artinya merubah atau mengganti sesuatu dengan sesuatu yang lain, sehingga jika dikatakan istabdalahu maka maksudnya adalah ittakhadha minhu badalan yakni menjadikan sesuatu sebagai pengganti dari yang lain (Majma' al-Lughah al-Arabiyah, 1991).

Sedangkan secara istilah, ada 2 ungkapan yang digunakan oleh ulama terkait dengan penukaran harta wakaf, yaitu ibdāl dan istibdāl. Menurut para Fukaha, ibdāl adalah menjual harta wakaf dengan gantinya baik yang berupa benda atau uang. Sedangkan istibdāl adalah membeli barang yang lain untuk menjadi pengganti barang wakaf yang dijual (Abu Zahra, 1959: 183). Sedangkan menurut al-Kabisi (2004: h. 349), ibdāl adalah menjual barang wakaf untuk membeli barang lain sebagai gantinya. Sedangkan istibdāl adalah menjadikan barang lain sebagai pengganti barang wakaf asli yang dijual. Menurut Ahmad Sidiq (2012: 29-30), istibdāl dapat diklasifikasikan ke dalam dua pengertian: Pertama, istibdăl dalam pengertian yang luas, yaitu pembelian, penjualan maupun tukar menukar benda wakaf; kedua, istibdāl dalam pengertian yang sempit, yaitu membeli benda secara kontan untuk dijadikan benda wakaf.

\section{Pendapat ulama fikih tentang istibdāl wakaf}

Para ulama fikih berbeda pendapat tentang hukum istibdāl. Sebagian mereka melarang secara mutlak, sebagian lagi melarang, kecuali ada kondisi tertentu yang menuntut untuk terjadinya istibdāl, dan sebagian lagi memperbolehkan, karena adanya syarat wakif atau karena alasan keuntungan lebih yang akan didapat dari istibdāl tersebut (Abu Zahra, 1959:183).

Mazhab Maliki dan Mazhab Syafi'i adalah mazhab yang terkesan ketat dalam memperbolehkan praktik istibdäl. Menurut kedua mazhab tersebut hukum asal dari wakaf adalah dilarang untuk dijual, dihibahkan, atau diwariskan. Hal tersebut sebagaimana hadis Nabi Muhammad SAW: 


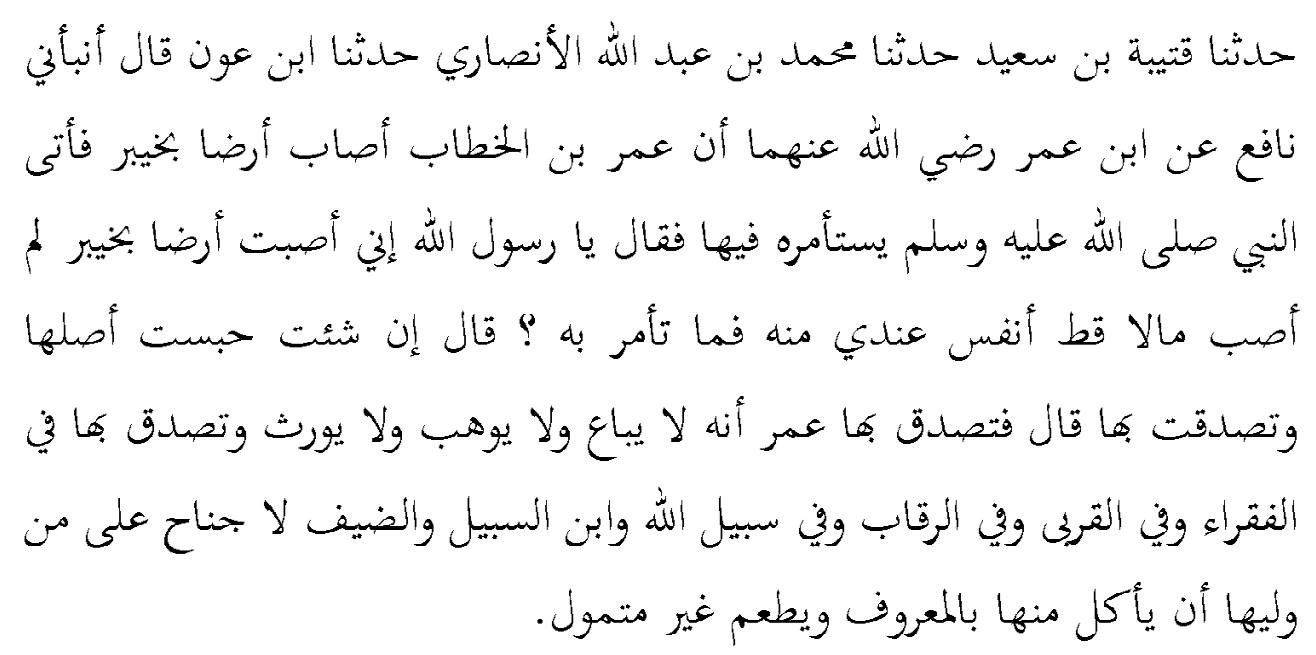

Sejalan dengan pendapat Mazhab Maliki dan Mazhab Syafi'i adalah mazhab Syiah Ja'fariyah yang sangat berhati-hati dalam melakukan praktik istibdäl bahkan mereka cenderung melarang praktik tersebut selama tidak ada kebutuhan yang mendesak. Pandangan tersebut sebagai konsekuensi atas prinsip mazhab yang berpendapat bahwa hukum asal dari menjual harta wakaf adalah dilarang (al-Kabisi, 2004:381).

Mazhab Hanafi dan Mazhab Hanbali lebih terlihat adaptif dan cenderung mempermudah izin praktik istibdāl selama ada kemaslahatan yang menghendakinya, bahkan menurut Sabri, mazhab Hanbali merupakan mazhab yang terlihat memperluas dan toleran dalam praktik istibdāl dalam rangka menjaga keberlangsungan harta wakaf.

Kedua mazhab sepakat memperbolehkan praktik istibdāl, manakala benda wakaf sudah tidak memberikan manfaat dan diyakini dengan praktik istibdālakan mendatangkan manfaat kepada benda wakaf tersebut. Akan tetapi keduanyan berbeda dalam menyikapi istibdāl masjid, di mana mazhab Hanbali membolehkannya karena alasan darurat, sedangkan Mazhab Hanafi melarangnya. Di samping itu, Mazhab Hanafi memberikan perhatian penuh terhadap syarat wakif yang mencantumkan istibdāl dalam akad wakafnya, sedangkan Mazhab Hanbali tidak demikian.

\section{Syarat-syarat istibdāl wakaf}

Berdasarkan pendapat ulama Mazhab yang telah dijelaskan sebelumnya dapat disimpulkan 
ljthad, Jurnal Wacana Hukum Islam dan Kemanusiaan, Volume 17, No. 1, Juni 2017: 39-60

bahwa hukum asal istibdāl terhadap benda wakaf adalah dilarang kecuali karena kondisi darurat atau ada kemaslahatan dalam rangka menjaga keberlangsungan manfaat benda wakaf tersebut secara terus menerus yang merupakan esensi dari wakaf. Kesimpulan tersebut juga dinyatakan oleh Al-Kabisi dan Abu Zahrah yang menyatakan bahwa dasar kebolehan istibdāl adalah kondisi darurat dan kemaslahatan, karena hukum asal dari istibdāl adalah haram kecuali ada alasan darurat dan alasan demi menjaga tujuan wakaf itu sendiri.

Agar istibdäl wakaf tidak disalahgunakan atau menjadi wasilah untuk mengambil keuntungan pribadi, yang berakibat kerugian pada harta benda wakaf yang ditukar, maka para fukaha telah memberikan syarat-syarat dalam istibdal untuk menghindari terjadinya kerugian benda wakaf.

Salah seorang ulama Mazhab Hanafi, al-Turtusi sebagaimana yang dikutip oleh Abu Zahrah mengajukan beberapa syarat istibdāl wakaf, yaitu: Pertama, hakim telah mengadakan penelitian atau kajian yang cermat tentang kelayakan dilakukannya istibdāl; Kedua, Membebankan kepada dua orang yang ahli atau professional, adil, amanah untuk mengkaji dan menganalisis sisi kejelasan atau nilai positif dari wakaf tersebut manakala dilakukan istibdal. Ketiga, Meregistrasi proses istibdāl dalam bentuk tertulis. Keempat, Hakim yang berwenang dalam masalah ini harusah hakim yang memiliki kompetensi ilmu dan pengalaman, adil dan amanah, atau dalam istilah fikih disebut dengan Qädi al-Jannah.

Al-Kabisi menyebutkan beberapa syarat yang harus diperhatikan dalam pelaksanaan istibdāl, syarat ini dikemukakan oleh sejumlah ulama mazhab Hanafi, sebagai berikut: Pertama, Istibdāl tidak boleh mengandung penipuan yang keterlaluan (gabn fahish). Kedua, aset wakaf tidak dijual kepada orang yang tidak jujur atau orang yang tidak diterima kesaksiannya (fäsiq), atau orang yang tersangkut hutang, atau orang yang memberi pinjaman hutang. Alasannya adalah penjualan kepada orang fasiq, diduga kuat akan terjadi penipuan. Sedangkan larangan penjualan kepada orang yang memberi pinjaman hutang dikhawatirkan terjadi penggunaan uang hasil penjualan akibat ketidak mampuan nazhir dalam melunasi hutangnya. Ketiga, istibdāl harus dalam bentuk benda tidak bergerak seperti tanah ('aqr), bukan berupa uang, karena jika berupa uang, dikhawatirkan uang tersebut akan habis atau disalah gunakan nazhir. Keempat, jika istibdāl dilakukan oleh hakim, maka yang ditunjuk adalah hakim yang memiliki rekam jejak yang baik (al-Kabisi, 2004:365). 
Khusus untuk istibdāl yang berupa rumah, Ibnu Nujaim menambahkan syarat yang lain, yaitu istibdāl hanya boleh dilakukan dalam satu wilayah dan kondisi rumah pengganti harus lebih baik dari sebelumnya. Selain itu, harta pengganti harus berupa tanah bukan uang, sebab jika berupa uang, dikhawatirkan membuka peluang terjadinya tindak korupsi (Abu Zahra, 1959:16).

Abu Zahra (1957:197) mengemukakan beberapa syarat yang harus dipenuhi dalam pelaksanaan istibdāl benda wakaf. Pertama, tidak ada kecurangan yang mengakibatkan terjadinya kezaliman dan praktik manipulasi dalam transaksi istibdāl.

Kedua, hakim atau pemerintah tidak boleh menjual aset wakaf kepada orang yang tidak diterima kesaksiannya (fásiq), atau para debitur dari hakim atau pemerintah karena dikhawatirkan terjadinya kebohongan maupun manipulasi atas harta wakaf. Ketiga, telah jelas bahwa benda pengganti aset wakaf yang telah dijual memiliki nilai manfaat yang lebih dan jauh dari bahaya serta kesulitan.

Sementara al-Zuhaily (2007:193) menyebutkan beberapa syarat yang hampir sama dengan pendapat ulama-ulama terdahulu. Pertama, aset wakaf dijual karena benar-benar sudah tidak bisa dimanfaatkan lagi. Kedua, aset wakaf sudah tidak memberikan hasil lagi yang dapat memakmurkan wakaf itu sendiri. Ketiga, pihak yang berwenang melaksanakan istibdäl adalah hakim yang memiliki reputasi baik atau Qädi Jannah.

Keempat, benda pengganti dalam istibdāl wakaf harus berupa benda tidak bergerak atau tanah, atau boleh saja dengan uang selama pelaksananya adalah Q $\bar{a}$ di al- Jannah.

\section{Ketentuan teknis pelaksanaan istibdāl wakaf di Indonesia}

Terkait dengan istibdāl wakaf, UU No. 41 Tahun 2004 tentang wakaf menyebutkan materi tentang penukaran harta wakaf, yaitu sebagaimana yang disebutkan dalam pasal 40 dan 41 pada Bab Perubahan Status Harta Benda wakaf. Harta benda wakaf yang sudah diwakafkan dilarang: a. dijadikan jaminan; b. disita; c. dihibahkan; d. dijual; e. diwariskan; f. ditukar; atau g. dialihkan dalam bentuk pengalihan hak lainnya.

Sedangkan Pasal 41 berbunyi:

(1) Ketentuan sebagaimana dimaksud dalam Pasal 40 huruf f dikecualikan apabila harta benda wakaf yang telah diwakafkan digunakan untuk kepentingan umum 
ljtihad, Jurnal Wacana Hukum Islam dan Kemanusiaan, Volume 17, No. 1, Juni 2017: 39-60

sesuai dengan rencana umum tata ruang (RUTR) berdasarkan ketentuan peraturan perundang-undangan yang berlaku dan tidak bertentangan dengan syariah. (2) Pelaksanaan ketentuan sebagaimana dimaksud pada ayat (1) hanya dapat dilakukan setelah memperoleh izin tertulis dari Menteri atas persetujuan Badan Wakaf Indonesia. (3) Harta benda wakaf yang sudah diubah statusnya karena ketentuan pengecualian sebagaimana dimaksud pada ayat (1) wajib ditukar dengan harta benda yang manfaat dan nilai tukar sekurang. kurangnya sama dengan harta benda wakaf semula. (4) Ketentuan mengenai perubahan status harta benda wakaf sebagaimana dimaksud pada ayat (1 ),ayat (2), dan ayat (3) diatur lebih lanjut dengan Peraturan Pemerintah.

Badan Wakaf Indonesia, telah mengeluarkan Peraturan Nomor 1 Tahun 2008 tentang Prosedur Penyusunan Rekomendasi terhadap Permohonan Penukaran/Perubahan Status Harta Benda Wakaf. Dalam Peraturan Penukaran Harta Benda Wakaf yang dikeluarkan oleh BWI, disebutkan syarat-syarat untuk dapat terlaksananya istibdāl wakaf, di antaranya disebutkan dalam pasal 4 Peraturan BWI, yang berbunyi:

1. Perubahan status harta benda wakaf dalam bentuk penukaran dilarang kecuali dengan izin tertulis dari Menteri berdasarkan pertimbangan BWI. 2. Izin tertulis dari Menteri sebagaimana dimaksud pada ayat (1) hanya dapat diberikan dengan pertimbangan sebagai berikut: a. perubahan harta benda wakaf tersebut digunakan untuk kepentingan umum sesuai dengan Rencana Umum Tata Ruang (RUTR) berdasarkan ketentuan Peraturan Perundang-undangan dan tidak bertentangan dengan prinsip syariah; b. harta benda wakaf tidak dapat dipergunakan sesuai dengan ikrar wakaf; atau c. pertukaran dilakukan untuk keperluan keagamaan secara langsung dan mendesak. 3. Selain dari pertimbangan sebagaimana dimaksud pada ayat (2), izin pertukaran harta benda wakaf hanya dapat diberikan jika: a. harta benda penukar memiliki sertifikat atau bukti kepemilikan sah sesuai dengan Peraturan Perundang-undangan; dan nilai dan manfaat harta benda penukar sekurang-kurangnya sama dengan harta benda wakaf semula. (4) Nilai dan manfaat harta benda penukar sebagaimana dimaksud pada ayat (3) huruf b ditetapkan oleh Bupati/Walikota berdasarkan rekomendasi tim penilai yang anggotanya terdiri dari unsur: a. pemerintah daerah kabupaten/kota; b. kantor pertanahan kabupaten/kota; c. Majelis Ulama Indonesia (MUI) kabupaten/kota; d. kantor Departemen Agama kabupaten/kota; dan e. Nazhir tanah wakaf yang bersangkutan.

Dalam Pasal 5 disebutkan bahwa harta benda penukar harus memiliki NJOP dan berada di wilayah yang strategis serta berkembang, sebagai berikut: 
Nilai dan manfaat harta benda penukar sebagaimana dimaksud dalam Pasal 4 ayat (3) huruf b dihitung sebagai berikut: a. harta benda penukar memiliki Nilai Jual Objek Pajak (NJOP) sekurang-kurangnya sama dengan NJOP harta benda wakaf; dan b. harta benda penukar berada di wilayah yang strategis dan mudah untuk dikembangkan.

Adapun metode penelitian ini adalah penelitian studi kasus. Teknik pengumpulan data dilakukan melalui observasi, wawancara, dan dokumentasi. Wawancara dilakukan kepada pihak-pihak yang mengetahui kasus penukaran Tanah wakaf Masjid Agung Semarang. Data telah terkumpul kemudian dianalisis secara deskriptif.

\section{Penukaran tanah wakaf masjid agung Semarang dengan tanah milik PT Sambirejo}

Pada tahun 1976, atas saran beberapa pihak, Majlis Ulama Indonesia (MUI) Kodya Semarang menerbitkan fatwa tertanggal 13 Oktober 1976 tentang istibdäl al-waqf atau penukaran tanah wakaf. Fatwa tersebut dilatar belakangi oleh tidak produktifnya tanah wakaf yang ada. Atas dasar pertimbangan tersebut, BKM Kotamadya Semarang mengadakan lelang untuk mencari pihak-pihak yang sanggup mencari penukar tanah bondo masjid (Tim Peneliti Masjid Agung Jawa Tengah, 2008:78-79).

Dalam Surat BKM Kota Semarang kepada Kakanwil Departemen Agama, tertanggal 23 Nopember 1990 disebutkan alasan penukaran tanah bondo Mesjid Besar Semarang adalah karena tanah sawah yang kurang produktif, belum ada sertifikatnya, dan berdasarkan planologi Kota Semarang akan dipergunakan untuk daerah pemukiman. Disamping itu juga semakin banyak pendirian bangunan rumah-rumah di atas tanah milik BKM.

Menteri Agama menerbitkan KMA No. 12 Tahun 1980 tertanggal 1 Maret 1980 yang berisi penunjukkan PT. Sambirejo Semarang sebagai penukar bondo Masjid Besar Semarang. Dalam lampiran KMA No. 12 Tahun 1980 tersebut dinyatakan bahwa tanah Masjid Besar Semarang yang ditukar adalah seluas 119,1270 ha, sedangkan tanah yang tidak ditukar seluas 9,9870 ha (Lampiran KMA No. 12 Tahun 1980).

Berdasarkan lampiran KMA No. 12 tahun 1980 tersebut, tanah bondo masjid yang luasnya 119,1270 ha akan ditukar dengan tanah pertanian yang lebih produktif seluas 250 ha yang berlokasi di Kabupaten Demak. 5 (lima) tahun pasca keluarnya KMA No. 12 tahun 1980, tentang penunjukkan PT. Sambirejo sebagai pihak penukar, Pada tanggal 3 Maret 1985 baru terlaksana akad serah terima tukar menukar tanah bondo Masjid Besar Semarang. Wakil 
ljtihad, Jurnal Wacana Hukum Islam dan Kemanusiaan, Volume 17, No. 1, Juni 2017: 39-60

dari BKM Pusat adalah Drs. HM. Munir, S.A. Sedangkan wakil dari PT. Sambirejo adalah Drs. Gatot Suwiryo. BKM menyerahkan tanah bondo Masjid Besar Semarang seluas 1.191.170 $\mathrm{m}^{2}$, dengan tanah penukar dari PT. Sambirejo seluas $2.504 .272 \mathrm{~m}^{2}$.

Enam tahun setelah terjadi proses tukar guling, ternyata terungkap lewat temuan tim BPK Pusat tanggal 17-28 Februari 1991 bahwa tanah penukar dari PT. Sambirejo sebagian besar adalah tanah fiktif atau bersertifikat palsu. Dari 250 ha tanah yang dijanjikan sebagai penukar, hanya 66,2 ha yang ada tanahnya dan bersertifikat BKM, sedangkan $1.842 .176 \mathrm{~m}^{2}$ adalah fiktif (Yusuf, 2000:48-49). Atas temuan BPK tersebut, tanggal 29 April 1991, ketua BKM Pusat meminta pertanggung-jawaban PT. Sambirejo, dan PT. Sambirejo berjanji akan menyelesaikannya dalam waktu 8 bulan. Akan tetapi pada perkembangannya PT. Sambirejo tidak memenuhi janjinya tersebut.

Pada tanggal 21 Agustus 1991 Direktur Urusan Agama Islam selaku ketua umum BKM Pusat mengirim surat kepada Walikota Semarang agar melakukan pemblokiran atas tanahtanah eks bondo Masjid Besar Semarang. Pada saat yang sama Gubernur Jawa Tengah mengirim surat kepada PT. Sambirejo tertanggal 16 Oktober 1991 yang isinya menolak pembebasan lokasi dan meminta PT. Sambirejo menyelesaikan terlebih dahulu permasalahannya dengan BKM. Untuk menghindari adanya penyerobotan, Walikota Semarang melalui suratnya tertanggal 5 Februari 1992 memerintahkan Kepala Kantor Pertanahan Kodya Semarang agar memblokir tanah-tanah eks bondo Masjid Besar Semarang (Tim Peneliti MAJT, 2008:87).

Pada tahun 1992, Menteri Agama membentuk tim penyelesaian kasus tukar menukar tanah wakaf Masjid Besar Semarang melalui KMA No. 134. Pada tanggal 24 Juli 1993 Tim Penyelesaian mengirim surat kepada Menteri Agama yang isinya agar mencabut KMA No.18 tahun 1985 tentang Pengesahan Penyelesaian Tukar Menukar Tanah Bondo Masjid Besar Semarang. Akan tetapi usulan itu baru diresposn oleh Menteri Agama setelah tiga tahun berjalan, dengan menerbitkan KMA No. 472 tahun 1996 yang mencabut KMA No.18 tahun 1985 dan memerintahkan kepada BKM Pusat untuk melakukan tuntutan pidana dan perdata kepada PT. Sambirejo.

Pada tanggal 19 Juni 1997, BKM Pusat mengajukan gugatan terhadap PT. Sambirejo melalui Pengadilan Negeri Semarang. Pada tanggal 30 Desember 1997, Pengadilan Negeri Semarang dalam dictum putusannya, antara lain menolak gugatan BKM Pusat. Atas putusan 


\section{Penukaran tanah wakaf masjid agung Semarang dalam perspektif fikih istibdal (Ahmad Furqon)}

tersebut BKM Pusat mengajukan banding. Tanggal 12 Februari 1998 BKM Pusat mengajukan memori banding ke Pengadilan Tinggi melalui pengacara Soeprapto, SH. Tanggal 18 Juni 1998, Putusan Pengadilan Tinggi Semarang No. 133/Pdt.1998 PT.Smg menyatakan BKM kalah pada tingkat banding.

Lamanya proses pemeriksaan dan persidangan yang berakhir dengan kekalahan BKM pada tingkat pertama dan banding menyebabkan banyaknya tanah wakaf bondo Masjid Besar Semarang yang berganti kepemilikan atau dihuni secara ilegal. Hal tersebut dikarenakan sejak akad serah terima tukar menukar, PT. Sambirejo melakukan penjualan terhadap tanah wakaf tersebut baik kepada masyarakat, perseorangan maupun perusahaan. Diantaranya dibeli oleh Walikota Semarang saat itu Soetrisno Soeharto, yang kemudian didirikan SPBU (Yusuf, 2000:123).

Tanggal 11 Maret 1998, melalui KMA No.110 tahun 1998, Menteri Agama membentuk tim terpadu penyelesaian kasus tukar menukar tanah Bondo Masjid Besar Semarang, yang terdiri dari unsur: Departemen Agama Pusat, Bakorstanasda Jateng dan DIY, Kanwil Departemen Agama Jateng, BKM Pusat, dan BKM Jateng. Kemudian tim tersebut dibagi menjadi 3 (tiga), yaitu: tim penyelesaian di Kabupaten Demak, tim penyelesaian di Kodya Semarang, dan tim penyelesaian hukum.Tim penyelesaian di Kabupaten Demak menemukan dan mendata tanah-tanah tukar menukar yang berada di Demak seluas $\pm 662.098 \mathrm{~m}^{2}(66,2$ ha). sedangkan tim penyelesaian di Kodya Semarang menemukan dan mendata tanah yang masih sertifikasi atas nama BKM seluas $\pm 692.972 \mathrm{~m}^{2}$ (69,2 ha).

Tanah bondo Masjid Besar Semarang yang berada di Kota Semarang dikuasai oleh Tjipto Siswoyo selaku direktur PT. Tensindo. Disinyalir, Tjipto Siswoyo adalah orang yang mendanai operasional PT. Sambirejo dalam proses tukar menukar dengan BKM, dengan janji akan mendapatkan tanah di Semarang (Yusuf, 2000:168).

Berbagai desakan dari anggota Muspida, ulama, dan masyarakat meminta Tjipto Siswoyo mengembalikan tanah Bondo Masjid Semarang yang dikuasainya. Pada tanggal 23 Desember 1999, keluar pernyataan dari Tjipto Siswojo bahwa ia bersedia mengembalikan tanah bondo Masjid Besar Semarang yang berada di Semarang, seluas 69,2 ha. Sesuai kesepakatan, 25\% dari tanah tersebut kembali kepada Tjipto Siswojo, sedangkan 75\% kembali kepada BKM Kota Semarang, yaitu 51,9 ha. Akhirnya pada tanggal 24 Desember 1999 terjadi serah 
ljtihad, Jurnal Wacana Hukum Islam dan Kemanusiaan, Volume 17, No. 1, Juni 2017: 39-60

terima tanah bondo Masjid Besar Semarang dari Tjipto Siswoyo kepada BKM Kota Semarang.

Tanah wakaf Masjid Besar Semarang yang dikelola oleh BKM Kota Semarang pasca penyerahan kembali oleh PT. Sambirejo, tidak semuanya bebas dari masalah dan siap untuk diproduktifkan. Pasca tukar guling yang bermasalah tersebut, tersimpan masalah pada status tanah penukar yang diberikan PT Sambirejo kepada BKM.

Tanah yang ditukar di Desa Werdoyo Kecamatan Dempet, sebagian adalah milik negara bukan tanah milik perorangan. Tanah penukar yang berada di Desa Wonoagung adalah tanah kosong yang tidak bisa digarap karena karena terkena rob pada musim kemarau dan tergenang air hujan pada musim penghujan. Termasuk juga lahan yang berada dipinggir pantai, sehingga tanah kosong tersebut setiap tahunnya terkena abrasi pantai.

Tanah penukar yang berada di Desa Wonokerto Kecamatan Sayung, tidak jelas lokasinya, karena masyarakat masih merasa belum dibayar lunas atas tanah-tanah mereka yang dibeli oleh PT. Sambirejo. Bahkan pada akhirnya dinyatakan oleh sebagian lurah di Kecamatan Sayung, bahwa tanah-tanah BKM di kecamatan tersebut tidak ada, karena dalam kesepakatan penggarap dengan PT. Sambirejo, tanah-tanah tersebut bukan dibeli akan tetapi hanya disuruh menggarap untuk selamanya, sedangkan hasilnya akan diberikan kepada BKM Kota Semarang. PT. Sambirejo hanya memberi uang muka sebagai imbalan sewa tanah dengan jumlah yang tidak sama.

Begitu pula terhadap tanah penukar di Desa Wonowoso Kecamatan Sayung, perangkat desa tidak bersedia menunjukkan lokasi tanah penukar yang dibeli PT. Sambirejo, karena PT. Sambirejo belum memenuhi seluruh kewajibannya. Walaupun akhirnya ditunjukkan lokasinya, akan tetapi ditunjukkan dari kejauhan, secara pandangan mata. Tanah-tanah yang ditunjukkan tidak pernah ditanami padi, karena tidak adanya irigasi. Musim tanamnya hanya tadah hujan. Tanah penukar di Desa Pilangsari Kecamatan Karang Tengah adalah tanah bengkok desa, sedangkan tanah tersebut dijual oleh pejabat lurah yang lama. Sedangkan perangkat desa tidak bersedia menunjukkan lokasi tanah BKM Semarang yang ada di desanya (BKM Kota Semarang, 1990).

Banyak yang menyayangkan terjadinya tukar menukar bondo Masjid Besar Semarang tersebut. Karena kalau alasannya untuk memproduktifkan tanah wakaf tersebut, tukar menukar bukan merupakan satu-satunya solusi. Menurut Agus Fathuddin Yusuf, mungkin 
tidak terpikirkan saat itu bahwa tanah yang terletak di kota sangat potensial untuk menghasilkan dana. Kalau tidak bisa ditanami padi, bisa ditanami benda yang lain, yang saat sekarang disebut dengan hutan beton. Sangat banyak dana yang bisa diperoleh seandainya tanah-tanah tersebut tidak ditukar (Yusuf, 2000:15).

Alasan kurang produktif tersebut dimungkinkan muncul karena adanya pemahaman mengenai bentuk produktifikasi tanah adalah dengan menjadikannya sebagai sawah atau kebun. Hal tersebut tercermin dalam alasan melakukan tukar menukar yang dikemukakan oleh pihak BKM, yaitu karena tanah yang dimiliki tidak menghasilkan, sehingga perlu dicari tanah penukar yang berbentuk sawah atau kebun yang produktif. Padahal sebenarnya tanah BKM yang berada di Kota Semarang, sangat potensial untuk diproduktifkan dalam bentuk selain sawah dan kebun. Seperti pertokoan, penginapan, gedung pertemuan, gedung olahraga yang bisa disewakan atau dikelola mandiri.

Motif terjadinya tukar menukar tanah BKM bisa jadi pula karena adanya keinginan segelintir orang untuk mengambil keuntungan dari proses tukar menukar tersebut untuk kepentingan pribadi. Hal tersebut dapat saja terjadi. Menurut Abu Zahra, Amir Jamaluddin, seorang penguasa Mesir pada masa dinasti Mamālik, jika melihat tanah wakaf yang prospektif, dan ia ingin memilikinya, maka ia akan menunjuk dua orang saksi untuk bersaksi bahwa lokasi tanah wakaf mengganggu tetangga sekitar atau orang yang berjalan, dan sebaiknya ditukar dengan yang lain, kemudian hakim Amr memutuskan untuk menukar tanah tersebut (Zahra, 1959:175).

Mustamaji, mantan pengurus BKM Kota Semarang, saat ditanya apakah alasan tukar menukar adalah murni untuk memproduktifkan tanah bondo Masjid Besar Semarang, atau ada motif lain?, menyatakan bahwa kemungkinan ada motif mengambil keuntungan pribadi atas tukar menukar tanah tersebut, yaitu keinginan pribadi Tjipto Siswoyo, yang melihat bahwa tanah wakaf bondo Masjid Besar Semarang ke depannya memiliki prospek ekonomi yang sangat besar. Salah satu bukti bahwa ini adalah kepentingan Tjipto Siswoyo, karena setelah diusut ternyata Tjipto Siswoyo yang membiayai PT. Sambirejo (Mustamaji, wawancara, 2016).

Sesungguhnya alasan karena tanah bondo Masjid Semarang sudah tidak produktif, atau karena mencari yang lebih baik adalah alasan yang lemah. Karena menurut Ibn Abidin, tukar menukar tidak bisa dilakukan terhadap harta wakaf yang masih memiliki manfaat secara 
ljtihad, Jurnal Wacana Hukum Islam dan Kemanusiaan, Volume 17, No. 1, Juni 2017: 39-60

keseluruhan, walaupun ada gantinya yang lebih baik. Walaupun Ibn Nujaim memperbolehkan penukaran harta yang masih ada manfaatnya secara keseluruhan, yang diistilahkan dengan alwaqf al-'amir, jika memang ada manfaat yang lebih baik. Akan tetapi mayoritas Mazhab Hanafi tidak memperbolehkan menukar al-waqf al-'amir (Ibn Abidin, 2003:4/384). Adapun alasannya menurut Ibn al-Hummam, karena tidak adanya faktor yang mengharuskan untuk melakukan penukaran tersebut. Menurut Mazhab Hanafi, ada dua faktor yang memperbolehkan terjadinya penukaran, yaitu karena adanya syarat dari wakif dan karena sebab darurat. Kedua hal ini tidak terpenuhi dalam al-waqf al-'amir, sehingga yang wajib adalah membiarkannya dalam kondisi awal tanpa ada tambahan (al-Maiman, 1430H:116).

Seharusnya tanah wakaf bondo Masjid Besar Semarang waktu itu, masih bisa dipertahankan untuk tidak ditukar, karena masih banyak solusi untuk memproduktifkannya selain dengan jalan tukar menukar atau istibdāl.

Dalam fikih istibdāl ada 6 (enam) syarat yang harus dipenuhi untuk terlaksananya istibdāl, yaitu: Pertama, harga penukar tidak boleh lebih murah dari harga tanah yang ditukar. Karena apabila lebih murah, maka hal tersebut adalah kezaliman, dan menyumbangkan (tabarru') sebagian tanah wakaf, hal tersebut tidak diperbolehkan, baik dilakukan oleh hakim atau selainnya. Kedua, orang yang membeli tanah yang ditukar adalah orang yang diterima persaksiannya atau orang yang tidak memiliki piutang dengan nazhir. Maka orang yang tidak diterima persaksiannya dilarang melakukan istibdāl, karena dikhawatirkan orang tersebut akan melakukan penipuan dalam proses istibdāl. Sedangkan larangan istibdāl kepada orang yang memiliki piutang dengan nazhir, dikhawatirkan harta wakaf akan hilang apabila nazhir tidak mampu melunasi utangnya. Ketiga, barang yang dibeli lebih baik dan tidak ada kerusakan dibandingkan barang yang dijual (Zahra, 1959:174). Keempat, tanah wakaf sudah tidak memberikan keuntungan untuk biaya pengembangannya. Kelima, tidak terjadi persekongkolan jahat di pengadilan dengan sengaja mengambil tanah wakaf untuk kepentingan pribadi atau golongan. Keenam, tanah ditukar dengan tanah, bukan dengan uang, karena uang beresiko hilangnya harta wakaf (Hamid, 2003:199). Syarat-syarat tersebut di atas menunjukkan bahwa sebelum dilakukan proses istibdäl harus dilakukan pengecekan, penelitian, atau observasi terlebih dahulu terhadap objek barang penukar dan orang yang akan membeli tanah wakaf tersebut. 
Menurut al-Ṭarsūsy sebagaimana yang dikutip oleh Abu Zahrah, yang berkewajiban melakukan pengecekan adalah hakim karena hakimlah yang berwenang untuk mengeluarkan izin istibdāl. Ada tiga tahapan yang dilakukan oleh hakim sebelum terlaksana proses istibdāl: Pertama, hakim meneliti secara langsung objek tanah yang ditukar dan tanah penukar; Kedua, hakim menugaskan dua orang yang adil, kompeten dan amanah untuk meneliti agar dapat disimpulkan bahwa proses istibdāl tersebut akan menguntungkan wakaf, kemudian mendengarkan kesimpulan keduanya; Ketiga, hakim memberi izin dan menuliskan ikrar istibdāl (Zahra, 1959:174)

Menurut Ulama Hanafiyah, proses tukar menukar dilakukan di pengadilan di hadapan Qādi al-Jannah, yaitu hakim yang adil, agar nazhir tidak mudah menjual harta wakaf, hingga menyebabkan kerugian (Daghi, 2004:32).

Dalam penukaran tanah wakaf bondo Masjid Besar Semarang antara BKM Kota Semarang dengan PT. Sambirejo, terkesan penukaran tersebut dilakukan tanpa pengecekkan yang optimal terhadap tanah penukar PT. Sambirejo terlebih dahulu. Hal tersebut disimpulkan karena akad penukaran Tanah Bondo Masjid Besar Semarang dengan tanah pertanian di Demak dilakukan pada tanggal 31 Maret 1980, sedangkan surat penunjukan Tim Teknis Penukaran Tanah Bondo Masjid Besar Semarang, baru ditanda tangani oleh Dirjen Bimas Islam dan Urusan Haji pada tanggal 3 Juni 1980. Langkah tersebut menyelisihi yang disampaikan oleh Abu Zahrah, dimana seharusnya pengecekan dilakukan oleh pihak yang kompeten dalam masalah tanah yaitu petugas Badan Pertanahan, notaris, dan pejabat tinggkat kelurahan dan kecamatan di mana tanah penukar tersebut berada. Pengecekan tersebut dilakukan sebelum pelaksanaan ikrar istibdāl.

Apabila melihat waktu terjadinya proses tukar menukar tanah wakaf yaitu pada medio 80-an, maka kemunginan peraturan perundang-undang yang dijadikan rujukan hukum adalah PP No.28 Tahun 1977 tentang Perwakafan Tanah Milik. Dalam PP tersebut terdapat pasal yang membahas mengenai perubahan perwakafan tanah milik, yaitu pasal 11, yang berbunyi:

Pada dasarnya terhadap tanah milik yang telah diwakafkan tidak dapat dilakukan perubahan peruntukkan atau penggunaan lain daripada yang dimaksud dalam Ikrar Wakaf. (2). Penyimpangan dari ketentuan tersebut dalam ayat (1) hanya dapat dilakukan terhadap halhal tertentu setelah terlebih dahulu mendapat persetujuan tertulis dari Menteri Agama, yakni: 
ljtihad, Jurnal Wacana Hukum Islam dan Kemanusiaan, Volume 17, No. 1, Juni 2017: 39-60

a. Karena tidak sesuai lagi dengan tujuan wakaf seperti diikrarkan oleh wakif. b. Karena kepentingan umum. (3). Perubahan status tanah milik yang telah diwakafkan dan perubahan penggunaannya sebagai akibat ketentuan tersebut dalam ayat (2) harus dilaporkan oleh nazhir kepada Bupati/Walikota Kepala Daerah cq.Kepala Sub Direktorat Agraria setempat untuk mendapatkan penyelesaian lebih lanjut.

Melihat pasal tentang perubahan tanah milik di atas, memang tidak menyebutkan siapa yang bertanggung jawab untuk melakukan pengawasan dan pengecekkan apabila terjadi penukaran tanah wakaf. Apabila merujuk pada ketentuan fikih, maka yang bertanggung jawab adalah hakim. Akan tetapi dalam peraturan wakaf di Indonesia, hakim tidak mengurus masalah penukaran wakaf. Sehingga yang bertanggung jawab dalam masalah pengecekkan adalah nazhir. Karena dalam Pasal 7 (1) PP No.28 Tahun 1977 tentang Perwakafan Tanah Milik menyebutkan kewajiban nazhir adalah mengurus dan mengawasi kekayaan wakaf. Peran ini tidak dijalankan oleh nazhir wakaf BKM Kota Semarang. BKM Kota Semarang beralasan bahwa dalam masalah tukar menukar tanah wakaf tersebut, yang melakukan kesepakatan adalah BKM Pusat, sehingga mereka tidak bertanggung jawab dalam masalah tukar menukar tersebut (Yusuf, 2000:74).

Menurut Mustamaji (wawancara, 2016), saat sebelum akad serah terima pada tahun 1985, tim pusat sudah turun mengecek tanah penukar, akan tetapi karena banyakknya tanah penukar dan terbatasnya jumlah tim pengecekan, proses pengecekan tersebut tidak maksimal. Tim hanya ditunjukkan tanah penukar dari jauh, tanpa melihat secara langsung akan tanah penukar tersebut.

\section{Penukaran tanah wakaf masjid agung Semarang dengan ma'had aly}

Istibdāl yang kedua dilakukan oleh BKM Kota Semarang terhadap tanah bondo Masjid Besar Semarang seluas 12.240 M2 yang terletak di Kelurahan Sambirejo, Kecamatan Gayamsari Kota Semarang dengan bangunan gedung Ma'had Aly senilai Rp. 6.122.500.000,- (enam milyar seratus dua puluh dua juta lima ratus ribu rupiah) dari Pemerintah Daerah Prov. Jawa Tengah bahwa berdasarkan kesepakatan tanggal 3 Maret 2008 antara Nazhir Badan Kesejahteraan Masjid (BKM) Kota Semarang, dengan Pemerintah Daerah Tingkat I Prov. Jawa Tengah Tanah Masjid Besar Semarang tersebut akan digunakan sebagai jalan raya 


\section{Penukaran tanah wakaf masjid agung Semarang dalam perspektif fikih istibdal (Ahmad Furqon)}

tembus akses masuk dari jalan Arteri Soekarno - Hatta menuju Masjid Agung Jawa Tengah (MAJT).

Istibdāl ini dituangkan dalam KMA No. 114 tahun 2008. Ada hal menarik, bahwa sebelum munculnya KMA 114 tahun 2008, muncul KMA No. 86 tahun 2008, yang menyebutkan pertukaran tersebut antara tanah BKM yang terletak di jalan Untung Suropati Manyaran, menjadi jalan tembus menuju MAJT. Padahal tanah yang berada di jalan Untung Suropati Manyaran, adalah digunakan sebagai Kantor Kementerian Agama Kota Semarang. Sehingga sesungguhnya KMA No. 114 tahun 2008, merupakan ralat terhadap KMA No. 86 tahun 2008. Kesalahan tersebut sangat disayangkan, karena menunjukkan ketidak telitian Kementerian Agama dalam mengeluarkan surat keputusan.

Pasal 40 UU No.41 tahun 2004 tentang Wakaf melarang istibdäl wakaf, kecuali untuk kepentingan umum sesuai dengan Rencana Umum Tata Ruang (RUTR), dengan syarat benda yang ditukar harus memiliki manfaat, dan nilai tukar sekurang-kurangnya sama dengan harta benda wakaf semula. Dalam penukaran tanah wakaf BKM ini memang peruntukannya adalah untuk menjadi jalan raya, yang berarti sudah sesuai dengan ketentuan perundangundangan. Akan tetapi penggantinya walaupun rencananya berbentuk Ma'had Aly, akan tetapi yang diberikan adalah uang sejumlah Rp. 6.122.500.000,- (enam milyar seratus dua puluh dua juta lima ratus ribu rupiah).

Al-Kabisi (2004:365) menyatakan bahwa diantara syarat pergantian adalah barang pengganti harus berupa barang yang tidak bergerak (iqär), bukan berupa uang Dinar atau Dirham. Ia mengutip perkataan Ibnu Nujaim yang mengatakan: "wajib ditambah satu syarat lagi untuk masa sekarang ini, yaitu mengganti dengan barang tidak bergerak bukan dengan Dirham atau Dinar, karena kita banyak menyaksikan nazhir menghabiskannya, dan sangat sedikit yang berpikiran untuk membeli penggantinya".

Dalam mazhab Syafi'i disyaratkan benda penganti harus sama dengan benda wakaf yang ditukar. Syarat tersebut dibuat oleh ulama karena khawatir apabila penukar benda wakaf berupa uang akan menyebabkan hilangnya benda wakaf tersebut. Karenanya apabila penukarnya adalah uang, maka uang yang diterima harus segera dibelikan tanah pengganti. Kalau tidak segera dibelikan tanah pengganti dikhawatirkan akan habis untuk penggunaan lain, atau harga properti akan naik, atau nilai tukar uang tersebut menurun, sehingga 
ljtihad, Jurnal Wacana Hukum Islam dan Kemanusiaan, Volume 17, No. 1, Juni 2017: 39-60

menyebabkan kerugian .

Syarat tentang tidak bolehnya mengganti tanah wakaf dengan uang juga dinyatakan oleh al-Zuhaily dengan alasan, moral dan sifat amanah nazhir yang berkurang pada masa sekarang ini. Ia menyebutkan memang ada sebagian pendapat yang membolehkan mengganti dengan uang, dengan syarat penerima pergantian dengan uang tersebut adalah gadi al-jannah , yaitu hakim yang adil (al-Zuhaili, 2007:193).

Sebenarnya pendapat az-Zuhaily ini digunakan oleh MUI Jawa Tengah sebagai dasar dalam merumuskan fatwa tentang kebolehan istibdāl tanah Masjid Besar Semarang menjadi jalan akses masuk Masjid Agung Jawa Tengah. MUI memandang penukarnya adalah bangunan Ma'had Aly. Akan tetapi faktanya, penukarnya adalah uang sejumlah Rp. 6.122.500.000,- (enam milyar seratus dua puluh dua juta lima ratus ribu rupiah).

Terhadap permasalahan penukaran tanah wakaf Masjid Besar Semarang dengan uang yang rencananya akan digunakan untuk membangun Ma'had Aly, penulis berpendapat walaupun ada yang membolehkan mengganti dengan uang, akan tetapi uang memiliki resiko yang besar, yaitu uang tersebut bisa habis dipakai atau nilainya menjadi turun, sehingga nilai uang yang diterima 7 (tujuh) tahun yang lalu berbeda dengan nilai uang diterima tahun ini, karena sampai awal tahun 2015, pembangunan Ma'had Aly belum dilaksanakan. Akan lebih baik pada saat penukaran, BKM langsung membelikan tanah pengganti atau meminta penggantian dalam bentuk tanah lagi, atau bangunan produktif, bukan dalam bentuk uang, atau wakaf konsumtif.

\section{Penukaran tanah wakaf masjid agung Semarang dengan sejumlah uang}

Penukaran ketiga terjadi terhadap tanah Masjid Besar Semarang yang terkena proyek pembangunan jalan Jolotundo yang menghubungkan jalan Kartini-jalan Gajah. Tanah Masjid Besar Semarang seluas 1.756m2, terletak di Kelurahan Sambirejo, Kecamatan Gayamsari Kota Semarang ditukar dengan uang senilai Rp.4,2 Milyar, dari Pemerintah Kota (Pemkot) Semarang (http://berita.suaramerdeka.com, diakses tanggal 23 Maret 2015).

Penukaran tanah telah terjadi, akan tetapi proses penggantiannya belum terlaksana. Pemkot Kota Semarang beralasan ada urusan administrasi yang belum lengkap, yaitu perlu pergantian nazhir yang baru, dikarenakan 2 dari 3 orang nazhir yang tercantum di dalam Sertifikat 


\section{Penukaran tanah wakaf masjid agung Semarang dalam perspektif fikih istibdal (Ahmad Furqon)}

Tanah Wakaf telah meninggal dunia (http://berita.suaramerdeka.com, diakses tanggal 23 Maret 2015).

Setelah lama menunggu, satu tahun setelah akad tukar ganti, pada tanggal 29 Februari 2016, Pemerintah Kota Semarang menggani Tanah wakaf Masjid Agung Semarang yang ditukar dengan uang senilai 4,2 Milyar Rupiah. Oleh Badan Pengelola Masjid Agung Semarang, yang saat ini mengelola sebagian aset tanah wakaf BKM Kota Semarang, uang pengganti tersebut digunakan untuk membeli tanah yang Jalan Alun-alun Selatan No 10 Kelurahan Kauman. Semarang Tengah, tepatnya di depan Masjid Kauman.

Lahan Masjid Kauman tersebut, ditukar dengan lahan seluas $272 \mathrm{~m} 2$ milik UmarToha senilai Rp 4.2 miliar. Ditambah bangunan yang ada di atasnya seluas $458.6 \mathrm{~m} 2$ senilai Rp 449 juta. Dengan demikian, jika ditotal harta benda lahan penukar ini sebanding dengan nilai lahan Masjid Kauman yang ditukar, senilai Rp 4.7 miliar.

Pola mengganti tanah yang terkena pelebaran jalan atau jalan umum dengan uang merupakan hal yang biasa terjadi. Akan tetapi untuk tanah wakaf, harus ada perlakuan khusus, tidak bisa disamakan dengan tanah bukan wakaf. Tanah wakaf hendaknya diganti dengan tanah juga. Pemkot memiliki aset tanah, maka tanah Pemkot tersebut dapat dijadikan tanah pengganti dari tanah yang ditukar tersebut.

Lamanya waktu pencairan sebenarnya menyebabkan kerugian pada nazhir. Karena nilai tanah yang diserahkan satu tahun yang lalu akan lebih tinggi pada saat sekarang ini, sedangkan kesepakatan harga telah ditetapkan satu tahun yang lalu, bukan berdasarkan harga tanah saat pencairan atau saat akan diganti uang. Pemerintah Kota Semarang beralasan bahwa molornya waktu pembayaran karena tiga nazhir yang tertera dalam sertifikat, tinggal satu orang yang masih hidup, sehingga perlu pergusulan nazhir pengganti atau pergantian nazhir baru, agar uang pengganti dapat dicairkan. Sedangkan untuk penetapan nazhir baru juga memerlukan waktu.

Menurut hemat penulis, ada kerancuan dalam penulisan nazhir BKM Kota Semarang. Seharusnya Nazhir BKM Kota Semarang adalah nazhir badan hukum bukan perseorangan, sehingga walaupun nazhirnya meninggal, akan tetapi karena yang tertera adalah badan hukum, maka tidak akan terhambat, akan tetapi yang terjadi ternyata nazhir BKM Kota Semarang, masih berbentuk nazhir perseorangan, karena ada penyebutan nama tiga orang nazhir.

Apa yang telah dilakukan oleh BP MAS dengan membelikan uang pengganti dengan 
ljtihad, Jurnal Wacana Hukum Islam dan Kemanusiaan, Volume 17, No. 1, Juni 2017: 39-60

tanah wakaf pengganti menurut hemat penulis sudah tepat. Hal tersebut dilakukan agar uang yang telah diterima tidak hilang, atau mengalami penurunan nilai, atau diselewengkan.

Akan tetapi apakah harga tanah pengganti sudah sesuai dengan harga pasar?. Menurut Tarsusy dari Mazhab Hanafi, penukaran tidak boleh dengan harga yang terlalu murah (gabn

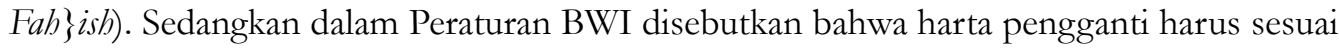
dengan NJOP harta penukar atau nilai pasar.

Apabila tanah pengganti adalah seluas $272 \mathrm{~m} 2$ yang dibeli dengan uang pengganti sebesar 4,2 Milyar rupiah, maka satu meternya adalah sebesar 15 juta 400 ribu rupiah. Menurut keterangan dari salah seorang pegawai pertanahan, harga tanah di Johar dan sekitarnya berkisar antara 10-15 Juta rupiah (Haris, wawancara, 2016). Berdasarkan pernyataan tersebut dapat disimpulkan bahwa pembelian tanah pengganti masuk dalam kategori harga pasar sehingga harganya tidak dianggap terlalu mahal.

\section{Penutup}

Adapun simpulan dari penelitian ini adalah sebagai berikut: Pertama, penukaran Tanah wakaf Masjid Agung Semarang yang pertama dengan PT Sambirejo tidak dilakukan penelitian secara mendalam terhadap tanah pengganti. Orang yang diajak melakukan transaksi dalam hal ini Cipto Siswoyo, dari PT. Sambirejo, masuk kategori yang tidak bisa diterima kesaksiannya, karena melakukan penipuan. Kedua, penukaranTanah wakaf Masjid Agung Semarang yang kedua, berupa uang untuk pembangunan Ma'had Aly, kurang dianjurkan oleh para ulama Fikih, karena nilai uang yang cenderung turun, dan rentan untuk dikorupsi dan disalahgunakan. Apalagi peristiwa penukaran terjadi tahun 2008, dan sampai tahun 2016, Ma'had Aly tersebut belum berdiri. Ketiga, penukaran Tanah wakaf Masjid Agung Semarang yang ketiga adalah juga dengan uang pengganti yang kemudian dibelikan tanah pengganti. Hal tersebut sudah tepat dan harga tanah pengganti masuk dalam harga pasar.

\section{Daftar pustaka}

Ahmad, Abdullah Salih Hamid. "Syart al-Wāqif wa Qadāāā al-Istibdāl", dalam Majalah Awqäf. Kuwait: al-Amānah al-'Āmah li al-Auqaf, Vol.3 no.5, 2003.

Al-Kabisi, Muhammad Abid Abdullah. A hlkäm al-Waqf fi al-Syari'ah al-Islamiyah. Terj. Ahrul Sani Fathurrahman. Jakarta: IIMaN \& Dompet Du’afa, 2004. 
—. Aḅkāam al-Waqf fi al-Syariah al-Istamiyah. Baghdad: Matba'ah al-Irsyād, 1977.

Al-Maiman, Nasir bin Abdullah. al-Nawazil al-Waqfiyah. Riyadh: Dar Ibn al-Jauzy, $1430 \mathrm{H}$. Al-Ubaidi, Ibrahim Abdul Latif Ibrahim. Istibdal al-Waqf; Ru'yat al-Syar'iyah Qanuniyah. Dubai: Dairah al-Syūn al-Islāmiyah wa al-'Amal al-Kahiry, 2009.

Anwar, dkk. Pemberdayaan Pengelolaan Wakaf di Kota Semarang. Penelitian tidak dipublikasikan. Semarang: Puslit IAIN Walisongo, 2008.

Asy-Sya'bi, Ahmad bin Abdul Jabbar. Al-Waqf Mafhūmuh wa Maqāsiduh, Makalah disampaikan dalam Nadwah al-Maktabāt al-Waqfiyyah, t.t.

Az-Zuhaily. Wașāya wa al-Waqf fi al-Fiqh al-Islamy. Beirut: Dār al-Fikr al-Mu'așir, 2007.

Fahd bin Muhammad al-Daud. al-Waqf wa Hụkmu Bai’ihi wa Istibdālih. Makalah disampaikan dalam Muktamar Wakaf I di Universitas Umm al-Qura Kerajaan Arab Saudi, tahun $1433 \mathrm{H}$.

Ibn Abidin, Muhammad Amin. Radd al-Mukhtâr 'alā al-Durr al-Mukhtär Syarh Tanwìr alAbshār. Beirut: Dār Ālam al-Kutub, 2003.

Ikrimah Sa'id Sabri. al-Waqf al-Islamy baina Nazariyah wa at-Tatbiqq. Amman: Dar an-Nafais, 2008.

Kementerian Pendidikan dan Pengajaran Mesir. al-Mu'jam al-Wajï. Republik Arab Mesir: Kementerian Pendidikan dan Pengajaran, 1991.

Majma' al-Lughah al-Arabiyah. al-Mu’jam al-Wajiz, Republik Arab Mesir: Kementerian Pendidikan dan Pengajaran, 1991.

Muhammad Abu Zahra. Muhädarät fi al-Waqf. Kairo: Matba'ah Ahmad Ali Mukhaimar, 1959.

Qurrah Daghi, Ali Muhyiddin. "Tanmiyyah Mawārid al-Waqf wa al-Huffaz 'Alaihā” dalam Majallah Awqäf. Kuwait: al-Amānah al-'Āmah li al-Auqaf Vol.7 No.7, 2004.

Siddiq, Achmad. Penerapan Prinsip al-Maslahah dalam Praktik Penukaran (Istibdäl) Harta Benda Wakaf di Indonesi. Disertasi pada UIN Walisongo Semarang, 2012.

Tim Peneliti Masjid Agung Jawa Tengah. Sejarah Masjid Besar Kauman Semarang dan Masjid Agung Jawa Tengah. Semarang: MAJT Press, 2008.

Wizārat al-Auqāf wa Shu'ūn al-Islāmiyah. al-Mausü'ah al-Fiqhiyyah. Kuwait: Wizārat al-Auqa>f wa Syu'ūn al-Islāmiyah, 1996.

Yusuf, Agus Fathuddin. Melacak Banda Masjid yang Hilang. Semarang: Aneka Ilmu, 2000.

Zahra, Muhammad Abu. Muḥādarāt fi al-Waqf. Kairo: Jamiat Dual a-Arabiyah, 1959.

Undang-undang No. 41 Tahun 2004 Tentang Wakaf. 
ljtihad, Jurnal Wacana Hukum Islam dan Kemanusiaan, Volume 17, No. 1, Juni 2017: 39-60

Peraturan Pemerintah No. 42 Tahun 2006 tentang Penjelasan Undang-Undang No. 41 Tahun 2004 tentang Wakaf.

Peraturan BWI Nomor 1 Tahun 2008 tentang Prosedur Penyusunan Rekomendasi terhadap Permohonan Penukaran/Perubahan Status Harta Benda Wakaf.

http://berita.suaramerdeka.com, diakses tanggal 5 Mei 2016.

Haris (Pegawai Badan Pertanahan Kota Kendal), wawancara tanggal 15 Agustus 2016, di BPI Ngaliyan Semarang, jam 17.30 WIB.

Mustamaji, Wawancara, tanggal 7 Juli 2016. 